Oleshko V, Young TanSung. Age dynamics of achieving sports results of the world best weightlifters at the stages of long-term perfection. Theory and Methods of Physical education and sports. 2020; 1: 15-25 DOI: 10.32652/tmfvs.2020.1.15-25
Олешко В, Янг ТанСунг. Вікова динаміка досягнення спортивних результатів найсильніших важкоатлетів світу на етапах багаторічного вдосконалення. Теорія і методика фрізичного виховання і спорту. 2020; 1: 15-25 DOI: $10.32652 /$ tmfvs.2020.1.15-25

\title{
ВІКОВА ДИНАМІКА ДОСЯГНЕННЯ СПОРТИВНИХ РЕЗУЛЬТАТІВ НАЙСИЛЬНІШИХ ВАЖКОАТЛЕТІВ СВІТУ НА ЕТАПАХ БАГАТОРІЧНОГО ВДОСКОНАЛЕННЯ
}

\author{
Валентин Олешко, Янг ТанСунг \\ Національний університет фізичного виховання і спорту України, Київ, Україна
}

\begin{abstract}
Анотація. Практика підготовки найсильніших важкоатлетів світу свідчить, що темпи становлення їхньої спортивної майстерності та вікові межі мають деякі відмінності залежно від етапів багаторічного вдосконалення. Meта. Визначити вікові межі та терміни досягнення спортивних результатів у найсильніших важкоатлетів світу на етапах багаторічного вдосконалення з урахуванням вагових категорій та статевих відмінностей. Методи. Аналіз наукової літератури, документальних матеріалів, узагальнення досвіду практичної роботи тренерів і спортсменів, педагогічні спостереження, аналіз та синтез вікових показників і спортивних результатів; математичне моделювання, методи математичної статистики. Результати. Вікові межі та терміни досягнення спортивних результатів у важкоатлетів світового рівня залежать від того, на якій стадії вони перебувають. Перша стадія охоплює період від початку занять спортом до виходу спортсмена на рівень вищих досягнень. Друга - відповідно від виходу спортсмена на рівень вищих досягнень до закінчення ним спортивної кар'єри. Терміни проходження важкоатлетками-жінками першої стадії суттєво менші (на 1,0-3,5 року), ніж у чоловіків. Вони витрачають менший часовий термін на період входження до групи світових лідерів (на 1-2 роки), порівняно з чоловіками. Зате чоловіки довший час зберігають високу результативність на другій стадії - 11-14 років, тоді як жінки тільки 8-11 років. Вікові межі входження важкоатлетів Китаю у другу стадію після участі у національних чемпіонатах становлять: у чоловіків у середньому 22 роки (через 1-2 роки), у жінок - 18-20 років відповідно (через 0,5-1 рік). Вікові межі, в яких вони зберігають свої високі спортивні результати, також мають відмінності: у чоловіків - 28-31 рік, у жінок на 2-3 роки менше, тобто у 26-28 років відповідно. Більшість (65,0 \%) спортсменів-чоловіків досягають високих результатів протягом 6-10 років, 24,0 \% - 11 років і більше, а 72,0 \% жінок - від 5 до 10 років відповідно.
\end{abstract}

Ключові слова: темпи досягнень, тривалість кар'єри, важкоатлети, вікові межі, статеві відмінності.

\section{Valentyn Oleshko, Young TanSung}

\section{AGE DYNAMICS OF ACHIEVING SPORTS RESULTS OF THE WORLD BEST WEIGHTLIFTERS AT THE STAGES OF LONG-TERM PERFECTION}

\begin{abstract}
The practice of training the world best weightlifters shows that the pace of development of their sportsmanship and age limits have some differences depending on the stages of long-term improvement. Objective. Determine the age limits and timing of achieving sports results by the world best weightlifters at the stages of longterm improvement, taking into account weight categories and gender differences. Methods. Analysis of scientific literature, documentary materials, generalization of experience of practical work of coaches and athletes, pedagogical observations, analysis and synthesis of age indices and sports results; mathematical modeling, methods of mathematical statistics. Results. The age limits and timing of achieving athletic results by world-class weightlifters depend on what stage they are at. The first stage covers the period from the beginning of sports engagement to entering the level of higher achievements. The second stage is from entering the level of higher achievements until the end of sports career. The duration of the first stage in female weightlifters is significantly shorter $(1,0-3,5$ years $)$ than in men. They spend less time joining the group of world leaders (1-2 years) than men. But men retain high performance for a long time in the second stage - 11-14 years, while women only 8-11 years. The age limits for Chinese weightlifters to enter the second stage after participating in national championships are: for men on average 22 years (after 1-2 years), for women - 18-20 years, respectively (after 0,5-1 years). The age limits in which they maintain their high sports results also differ: for men - 28-31 years, for women 2-3 years less, i.e. 26-28 years, respectively. The majority $(65,0 \%)$ of male athletes achieve high results within $6-10$ years, $24,0 \%-11$ years and more, and $72,0 \%$ of women - from 5 to 10 years, respectively
\end{abstract}

Keywords: rates of achievements, career duration, weightlifters, age limits, gender differences.

Вступ. Практичний досвід свідчить, що у спорті вищих досягнень для чоловіків побудовано ефективну систему моделювання термінів до- сягнення спортивних результатів у певних вікових межах на різних етапах багаторічного вдосконалення, тоді як системи моделювання таких кри- 
теріїв для жінок у повному обсязі ще не розроблено [3, 11, 12, 18]. Тому тренувальна та змагальна діяльність спортсменок у більшості випадків проводиться за методикою підготовки чоловіків, що негативно впливає на стан їхньої тренованості та здоров'я. В окремих роботах фахівці [3, 4, 12, 15] робили спроби віднайти відмінності між темпами досягнень у спортсменів різної статі, показниками змагальної діяльності, віковими межами цих досягнень на етапах багаторічного вдосконалення. Однак у силових видах спорту, до яких належить важка атлетика, проблема моделювання темпів спортивних досягнень за віковими межами не знайшла на сьогодні остаточного вирішення.

Деякі фахівці [1, 9, 14, 19] підкреслюють певну очевидність того, що високі спортивні результати найчастіше досягаються спортсменами 3 яскраво вираженою індивідуальністю, у тому числі й у процесі становлення спортивної майстерності. Тому вельми актуальним є визначення вікових меж та термінів становлення вищої спортивної майстерності, зумовлених, головним чином, віком початку занять, спрямованістю тренувального процесу на етапах підготовки та характером біологічного дозрівання спортсмена.

Багато фахівців, які спеціалізуються у важкій атлетиці [4, 8, 12, 15], вивчали динаміку досягнень важкоатлетів високої кваліфікації у зв'язку зі зміною їхніх вагових категорій. Водночас інші автори [5, 16, 18] вивчали тривалість періоду максимальної реалізації індивідуальних можливостей та збереження досягнень спортсменами. Ними встановлено, що спортивні досягнення важкоатлетів продовжують зростати в середньому протягом 12 років (від 10 до 14). Фахівці стверджують, що на виконання кожного ступеня спортивної кваліфікації найталановитіші важкоатлети витрачають у середньому близько 1-2 роки. На думку деяких авторів, важкоатлети легких вагових категорій виконують кваліфікаційні нормативи трохи швидше, ніж спортсмени важких вагових категорій. Згідно із дослідженнями [3, 7, 11], найбільше підвищення досягнень відмічається у важкоатлетів, які на шляху до етапу вищої спортивної майстерності переходили з однієї до наступної (більш високої) вагової категорії.

Деякі учені [3, 8, 10, 12, 18] встановили взаємозв'язок між термінами зростання спортивних досягнень та віком спортсменів. Виявляється, що чим менший вік, в якому атлети починали займатися спортом, тим нижчими є темпи зростання спортивних досягнень у перші роки тренувань, і навпаки, чим більший цей вік, тим вищі темпи зростання спортивних результатів. Отже приріст спортивних досягнень у найсильніших важкоатлетів світу відмічається у середньому протягом 14-17 років систематичних тренувань.

У теорії та практиці олімпійського спорту існує твердження, що терміни становлення спортивної майстерності у певних вікових межах на етапах ба- гаторічного вдосконалення мають деякі відмінності залежно від того, на яких із двох стадій перебувають спортсмени. Згідно з даними В. М. Платонова [14], процес багаторічної підготовки спортсменів високої кваліфікації у різних видах спорту може розділятися на дві тривалі стадії.

Перша стадія починається від початку занять видом спорту до виходу спортсмена на рівень підготовки до вищих досягнень. Вона зазвичай охоплює перші чотири етапи багаторічної підготовки: початкової, попередньої базової, спеціалізованої базової та підготовки до вищих досягнень.

Друга стадія охоплюе період від виходу спортсмена на рівень вищих досягнень до закінчення ним спортивної кар'єри. Вона також містить чотири етапи: максимальної реалізації індивідуальних можливостей, збереження високої спортивної майстерності, поступового зниження досягнень та виходу із спорту.

На думку відомих фахівців, на кожній із цих стадій існують свої об' єктивні критерії ефективності системи підготовки та організаційно-методичні форми побудови тренувального процесу спортсменів високої кваліфікації [2-4, 9, 12-14]. Критеріями ефективності підготовки спортсменів на першій стадії зазвичай є дотримання закономірностей становлення вищої спортивної майстерності в системі багаторічного вдосконалення, вихід на рівень вищих досягнень у нижній віковій межі, що є оптимальною для певного виду спорту, і важкої атлетики зокрема. Існує гіпотеза, що жінки проходять коротший шлях до вищих спортивних досягнень, ніж чоловіки. Критеріями ефективності підготовки спортсменів на другій стадії є досягнення найвищого результату на етапі максимальної реалізації індивідуальних можливостей та утримання його як можна довший час.

Оптимальні вікові межі спортсменів для досягнення високих результатів у більшості видів спорту досить сталі. Разом із цим, окремі чинники генетичного характеру, що зумовлені належністю деяких спортсменів до певної етнічної групи, спроможні суттєво змістити зону оптимальних можливостей у бік молодшого віку.

Мета дослідження - визначити вікові межі та терміни досягнення спортивних результатів у найсильніших важкоатлетів світу на етапах багаторічного вдосконалення з урахуванням вагових категорій та статевих відмінностей.

Методи дослідження: аналіз наукової літератури, документальних матеріалів, узагальнення досвіду практичної роботи тренерів і спортсменів, педагогічні спостереження, аналіз та синтез вікових показників і спортивних результатів; математичне моделювання, методи математичної статистики.

Результати дослідження та їх обговорення. У ході дослідження нами вивчались вікові межі спортивних досягнень важкоатлетів різної статі як 
Таблиця 1 - Вікові межі спортивних досягнень важкоатлетів високої кваліфікації протягом спортивної кар'єри (n = чол. - 200; жін. - 160)

\begin{tabular}{|c|c|c|c|c|c|c|c|c|}
\hline \multirow{3}{*}{$\begin{array}{c}\text { Вагова } \\
\text { категорія }\end{array}$} & \multicolumn{4}{|c|}{ Перша стадія, вік, років } & \multicolumn{4}{|c|}{ Друга стадія, вік, років } \\
\hline & \multicolumn{2}{|c|}{ Початок занять } & \multicolumn{2}{|c|}{$\begin{array}{c}\text { Найвищі досягнення на націо- } \\
\text { нальних чемпіонатах }\end{array}$} & \multicolumn{2}{|c|}{$\begin{array}{l}\text { Входження до групи } \\
\text { світових лідерів }\end{array}$} & \multicolumn{2}{|c|}{$\begin{array}{l}\text { Збереження досягнень } \\
\text { та завершення кар'єри }\end{array}$} \\
\hline & ч. & ж. & 4. & ж. & ч. & ж. & ч. & ж. \\
\hline Перша & $12-13$ & $13-14$ & $19-22$ & $18-20$ & $20-23$ & $19-21$ & $31-36$ & $29-31$ \\
\hline Друга & $12-13$ & $13-14$ & $20-23$ & $18-20$ & $21-23$ & $20-21$ & $31-36$ & $26-30$ \\
\hline Третя & $13-14$ & $13-14$ & $21-24$ & $19-22$ & $22-24$ & $21-23$ & $33-38$ & $28-32$ \\
\hline
\end{tabular}

Примітка: тут і далі, чоловіки: перша група - вагові категорії до 55,61,67 кг; друга група - 73,81,89 кг; третя група 96,102,109 і +109 кг; жінки: перша група - 45,49,55,59 кг; друга група - 64,71,76 кг; третя група - 81,87 і +87 кг.

всередині окремого етапу, так і на кожному з етапів багаторічного вдосконалення:

1) вікові межі спортсменів на початку занять важкою атлетикою;

2) вікові межі та терміни досягнення найвищих результатів на національних чемпіонатах;

3) вікові межі та терміни входження спортсменів до групи світових лідерів у певній ваговій категорії (до десятки найкращих важкоатлетів світу чи континенту);

4) вікові межі та терміни досягнення важкоатлетами найкращого результату за спортивну кар'єру;

5) вікові межі та терміни збереження високої спортивної майстерності (спортивних результатів);

6) вікові межі та терміни завершення занять видом спорту;

7) тривалість етапів багаторічної підготовки важкоатлетів та періоду збереження максимальних результатів протягом спортивної кар'єри.

На думку С. Н. Бубки, В. М. Платонова, «орієнтація на оптимальні для досягнення найвищих результатів вікові межі, що у цілому є доцільною для переважної більшості спортсменів, може бути порушена 3 боку окремих видатних спортсменів 3 яскравими індивідуальними особливостями. Віковий розвиток таких спортсменів, адаптаційні процеси, що розвиваються у їхньому організмі під впливом спеціального тренування, вимагають побудови індивідуального планування багаторічної підготовки, чи значного скорочення темпів досягнення певного етапу багаторічної підготовки. Рухова обдарованість таких спортсменів, виняткова лабільність основних функціональних систем, індивідуальні темпи розвитку дозволяють їм без порушень основних закономірностей багаторічної підготовки набагато швидше досягати вершин спортивної майстерності і показувати видатні результати часто-густо на 2-4 роки раніше за оптимальні вікові межі» [1].

Наведений вислів можна підтвердити на прикладі видатних важкоатлетів минулого століття Наїма Сулейманоглу (Туреччина), який став чем- піоном світу з важкої атлетики у 18 років, або Халіла Мутлу (Туреччина), який переміг на олімпійській арені у 19 років, а перший світовий рекорд встановив у 14 .

Ми вивчали вікові межі спортивних досягнень важкоатлетів високої кваліфікації різної статі та груп вагових категорій представників європейських країн на першій та другій стадіях багаторічного вдосконалення [10] (табл. 1).

Аналіз даних, представлених у таблиці 1, свідчить, що терміни проходження важкоатлеткамижінками першої стадії процесу багаторічного вдосконалення суттєво менші (на 1,0-3,5 року), ніж у чоловіків. Причому, з підвищенням вагових категорій спортсменів ця різниця стає меншою. Встановлену тенденцію підтверджують терміни досягнення та збереження високої результативності важкоатлетів на другій стадії процесу багаторічного вдосконалення. Жінки витрачають, зазвичай, менший часовий термін на період входження до групи світових лідерів (на 1-2 роки) порівняно 3 чоловіками. Окрім цього, чоловіки довший час зберігають високу результативність на другій стадії процесу багаторічного вдосконалення - 11-14 років, тоді як жінки тільки 8-11 років.

Нами також вивчались вікові межі спортивних досягнень важкоатлетів-чоловіків високої кваліфікації на етапах багаторічного вдосконалення за свою спортивну кар'єру, але у різні часові періоди своєї підготовки. Перший часовий період тренувального процесу охоплював вікові межі підготовки із 1956 по 1985 р., а другий - із 1986 по 2016 р., відповідно. Аналізу підлягали вікові межі спортивних досягнень спортсменів різних континентів, які досягли результатів світового рівня на Іграх Олімпіад та чемпіонатах світу (рис. 1).

Наведені дані свідчать про стрімко зростаючу за останні десятиріччя тривалість спортивної кар'єри видатних важкоатлетів у різних дисциплінах важкоатлетичного спорту. Якщо тривалість підготовки важкоатлетів на стадії Б у період 1956-1985 рр. (розвиток, реалізація та збереження вищої спортивної майстерності) становила 
Перший період (1956-1985 рр., $\mathrm{n}=36)$

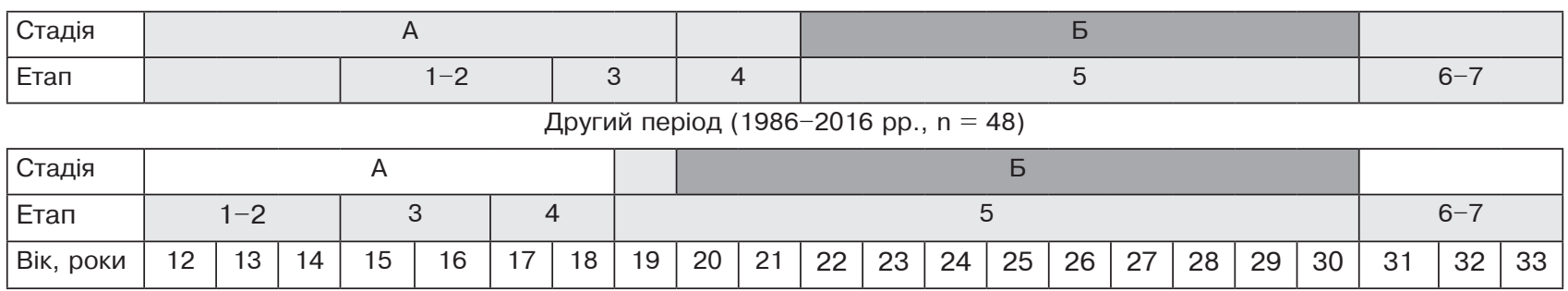

Рисунок 1 - Вікові межі спортивних досягнень важкоатлетів світового рівня на етапах багаторічної підготовки: стадії: А - становлення вищої спортивної майстерності; Б - розвиток, реалізація та збереження вищої спортивної майстерності; $\square$ - зона найвищих досягнень; етапи багаторічної підготовки: 1 - початковий, 2 - попередньої базової, 3 - спеціалізованої базової, 4 - підготовки до вищих досягнень, 5 - максимальної реалізації індивідуальних можливостей; 6 - збереження вищої спортивної майстерності; 7 - поступового зниження досягнень.

у середньому - 9,1 року, а вік важкоатлетів під час досягнення цього етапу становив - 20,9 року, то тривалість підготовки важкоатлетів у період 1986-2016 рр. на стадії Б уже зросла на 15,0% і становила - 10,7 року.

Така тенденція зберігається й у віковому цензі чоловіків на початку занять важкою атлетикою. Якщо у перший часовий період тренувального процесу (1956-1985 рр.) середній вік спортсменів на початку занять важкою атлетикою становив у середньому - 15,9 року, то у другий часовий період (1986-2016 рр.) їхній вік суттєво зменшився - на 22,6 \% та становив уже 12,3 року. Треба зазначити, що середній вік завершення п'ятого етапу багаторічної підготовки важкоатлетів світового рівня (максимальної реалізації індивідуальних можливостей) протягом двох вікових періодів майже не має відмінностей і становить 30,3 та 29,6 року відповідно.

Отже, сучасна практика занять важкою атлетикою значно змінює уявлення про тривалість та зміст етапів багаторічної підготовки важкоатлетів світового рівня, а це суттєво розширює вимоги до визначення нових закономірностей вдосконалення змісту принципів спортивного тренування та змісту підготовки важкоатлетів на різних її етапах.

3 іншого боку, вікові межі спортивних досягнень також залежать від статевих особливостей важкоатлетів. Стрімкий розвиток важкої атлетики серед жінок останніми роками інтенсивно продовжується, тому виникає необхідність визначення найбільш сприятливих вікових меж для досягнення спортсменками високих спортивних результатів із мінімізацією негативних наслідків для їхнього здоров'я.

Теорія і практика підготовки важкоатлетів високої кваліфікації в олімпійському спорті свідчать про те, що останні 15-20 років спортсмени Китаю займають лідируючі позиції на світовій міжнародній арені. Це підтверджено великою кількістю виграних медалей на змаганнях різного рангу: Іграх Олімпіад, чемпіонатах світу, Азії тощо. Одним із наших завдань було дослідження вікових меж та термінів досягнення спортивних результатів важ- коатлетами елітної групи на етапах багаторічного вдосконалення. У дослідженні брали участь понад 50 важкоатлетів КНР різної статі, які в різні роки були призерами Ігор Олімпіад, чемпіонатів світу та континенту. Всіх важкоатлетів було розподілено на групи вагових категорій, наведених вище. У таблиці 2 наведено вікові показники спортивних досягнень в елітній групі важкоатлетів Китаю на етапах багаторічного вдосконалення.

Аналіз даних, наведених у таблиці 2, свідчить, що китайські важкоатлети елітної групи (чоловіки та жінки) починають займатися цим видом спорту приблизно в одному й тому самому віці (у середньому в 10 років), окрім спортсменок третьої групи. Важкоатлети-чоловіки у середньому в 20 років (після 10 років підготовки) демонструють найвищі досягнення у дорослому національному чемпіонаті країни, тоді як у жінок цей вік становить 17-18 років (на 2-3 роки менше). Це пов'язано 3 тим, що у підлітковому віці юнаки та дівчата мають різні темпи статевого дозрівання (у дівчат він проходить більш інтенсивно). Така тенденція узгоджується 3 даними інших фахівців у галузі важкої атлетики [3, 5, 6, 11].

Середній вік входження важкоатлетів-чоловіків і жінок Китаю до групи світових лідерів після участі у національних чемпіонатах (друга стадія підготовки) становить у чоловіків 22 роки (у середньому через 1-2 роки після високих досягнень на національних чемпіонатах), а у жінок - 18-20 років відповідно (у середньому через 0,5-1 рік).

Середній вік, в якому важкоатлети Китаю різної статі зберігають високі спортивні результати та завершують свою кар'єру, становить: у чоловіків - 28-31 рік, у жінок - на 2-3 роки менше, у 26-28 років відповідно. Кількість років, протягом яких важкоатлети різної статі елітної групи зберігають свої спортивні досягнення становить: у чоловіків - 17-18 років; у жінок на 1,5 року менше, тобто - 15,5-16,5 року. Ці дані узгоджуються 3 результатами робіт, отриманими під час вивчення вікових показників важкоатлетів різної статі та груп вагових категорій із європейських країн [5, 7, 17, 18]. 
Якщо порівняти вікові показники спортивних досягнень важкоатлетів високої кваліфікації, які $€$ переважно представниками європейських країн, та спортсменів КНР, то простежується така закономірність. Вік початку занять видом спорту у важкоатлетів КНР є на 2-3 роки менший, ніж у спортсменів Європи. На вихід до найвищих досягнень на національних чемпіонатах важкоатлетичоловіки Китаю витрачають у середньому 10 років, а жінки на 2 роки менше. У представників Європи у чоловіків цей термін трохи менший і становить 7-8 років, а у жінок - 5-7 років, тобто на 1-2 роки менше.

Вікові межі термінів входження представників обох частин світу до групи світових лідерів приблизно однакові - 20-22 роки у чоловіків, у жінок цей вік у спортсменок Китаю відповідно менший 18-20 років, ніж у представниць Свропи - 19-21 рік. Щодо вікових меж збереження досягнень та завершення спортивної кар'єри, то тут також суттєва перевага на боці представників європейських країн. У чоловіків-важкоатлетів різних груп вагових категорій тривалість підготовки на всіх етапах багаторічного вдосконалення (від початку занять видом спорту до моменту завершення спортивної кар'єри) становить 21-22 роки, а у представників КНР у середньому на 3 роки менше, тобто 17-20 років. У жінок спостерігається дещо інша ситуація: у представниць Свропи тривалість підготовки на всіх етапах багаторічного вдосконалення становить 14,5-16,5 року, і у спортсменок Китаю майже така сама тривалість - 15-16 років.

Нами також вивчались терміни збереження максимальних результатів найсильнішими важкоатлетами світу на етапах багаторічного вдосконалення (табл. 3) [10].

Якщо тривалість основних етапів багаторічної підготовки важкоатлетів світового рівня прийняти за 100 \%, то у першій групі максимальні досягнення вони показували після 90,9 $\pm 3,3$ \% терміну всього періоду спортивного вдосконалення, у другій групі $-84,2 \pm 3,6 \%$, у третій групі відповідно $-74,5 \pm 3,2 \%(\mathrm{p}<0,05)$. Тобто відмічається тенденція, коли спортсмени важких вагових категорій раніше за атлетів легких вагових категорій досягають високих результатів, але потім довше утримують їх. Серед обстежуваної групи важкоатлетів тільки невелика їх частка (4,6 \%) демонструє збереження досягнень в останній рік багаторічного вдосконалення, а деякі із них $(2,8$ \%) показали ïх у середині відповідних етапів.

Нами також вивчалися терміни досягнення високої результативності (періоди успішних виступів) важкоатлетів різної статі у межах чотирирічних олімпійських макроциклів підготовки. Аналіз індивідуальної результативності свідчить, що 78,0 \% важкоатлетів-чоловіків мали найвищі досягнення на третьому та четвертому роках олімпійського макроциклу. Причому, 67,0% демонстрували ці досягнення, знаходячись на основних етапах багаторічного вдосконалення (від етапу підготовки до вищих досягнень, до етапу поступового їх зниження), тобто протягом 3-4 олімпійських циклів поспіль.

Середньорічний приріст високої результативності на етапах багаторічного вдосконалення (починаючи з етапу підготовки до високих досягнень) зумовлює індивідуальну перспективність того чи іншого важкоатлета. Аналіз індивідуальної результативності у середньому за відповідні роки підготовки свідчить про іï коливання від 0,4% у Анджея Цофаліка (Польща) до 25,0% у Хусейна Реза-Заде (Іран). Середньорічне коливання результатів атлетів за групами вагових категорій становить: у першій групі $-9,6 \pm 2,1 \%$, другій $-6,4 \pm 2,3 \%$ і третій $-5,7 \pm 0,8 \%$. Разом із цим, різниця між даними показниками першої i третьої груп вагових категорій недостовірна. Виявлена тенденція дає можливість встановити, що середньорічне коливання результативності важкоатлетів має суто індивідуальний характер і залежить, на нашу думку, від того, на якому році перебування на етапі максимальної реалізації індивідуальних можливостей атлет іï демонструє.

У таблиці 4 представлено терміни досягнення максимальних результатів спортсменками високої кваліфікації на етапах багаторічного вдосконалення.

Аналіз даних таблиці 4 свідчить, що у жінок, неодноразових призерів Ігор Олімпіад та чемпіонатів світу, індивідуальна результативність на етапах багаторічного вдосконалення (починаючи 3 етапу підготовки до вищих досягнень) коливаєть-

Таблиця 2 - Вікові показники спортивних досягнень ( $x \pm$ S) елітної групи важкоатлетів КНР протягом спортивної кар'єри (чоловіки $-\mathrm{n}=36$, жінки $-\mathrm{n}=16$ )

\begin{tabular}{|c|c|c|c|c|c|c|c|c|}
\hline \multirow{3}{*}{$\begin{array}{l}\text { Вагова } \\
\text { категорія }\end{array}$} & \multicolumn{4}{|c|}{ Перша стадія } & \multicolumn{4}{|c|}{ Друга стадія } \\
\hline & \multicolumn{2}{|c|}{ Початок занять } & \multicolumn{2}{|c|}{$\begin{array}{c}\text { Найвищі досягнення } \\
\text { на національних чемпіонатах }\end{array}$} & \multicolumn{2}{|c|}{$\begin{array}{l}\text { Входження до групи } \\
\text { світових лідерів }\end{array}$} & \multicolumn{2}{|c|}{$\begin{array}{l}\text { Збереження досягнень } \\
\text { та завершення кар'єри }\end{array}$} \\
\hline & 4. & ж. & 4. & ж. & 4. & ж. & 4. & ж. \\
\hline Перша & $10,6 \pm 0,2$ & $10,7 \pm 0,15$ & $20,1 \pm 0,02$ & $18,0 \pm 0,1$ & $21,9 \pm 0,03$ & $19,0 \pm 0,05$ & $27,9 \pm 0,35$ & $26,1 \pm 0,6$ \\
\hline Друга & $10,5 \pm 0,03$ & $10,5 \pm 0,1$ & $20,7 \pm 0,5$ & $17,7 \pm 0,2$ & $22,2 \pm 0,03$ & $18,3 \pm 0,09$ & $30,6 \pm 0,2$ & $26,5 \pm 0,7$ \\
\hline Третя & - & $12,5 \pm 0,5$ & - & $20,0 \pm 0,4$ & - & $20,75 \pm 0,4$ & - & $27,7 \pm 1,1$ \\
\hline
\end{tabular}


ТЕОРІЯ I МЕТОДИКА ФІЗИЧНОГО ВИХОВАННЯ І СПОРТУ № 1

Таблиця 3 - Терміни досягнення максимальних результатів найсильнішими важкоатлетами світового рівня

\begin{tabular}{|c|c|c|c|c|c|}
\hline \multirow[b]{2}{*}{ Спортсмен } & \multirow[b]{2}{*}{ Країна } & \multirow[b]{2}{*}{$\begin{array}{c}\text { Вагова } \\
\text { категорія, кг }\end{array}$} & \multicolumn{3}{|c|}{ Терміни досягнення, роки } \\
\hline & & & $\begin{array}{l}\text { Тривалість періоду } \\
\text { успішних виступів }\end{array}$ & $\begin{array}{c}\text { Терміни } \\
\text { досягнення MP }\end{array}$ & $\begin{array}{c}\text { Кількість чотирирічних } \\
\text { макроциклів, де були } \\
\text { показані MP }\end{array}$ \\
\hline Пешалов М. & Болгарія/Хорватія & 60,59 & 16 & 16 & 3 \\
\hline Бем А. & Німеччина & 67,$5 ; 70$ & 16 & 7 & 3 \\
\hline Веллер Р. & Німеччина & +105 & 14 & 14 & 4 \\
\hline Курлович О. & Білорусь & +110 & 14 & 5 & 3 \\
\hline Кахіашвиліс A. & Греція & 94,99 & 13 & 5 & 3 \\
\hline Сулейманоглу Н. & Туреччина & 60,64 & 13 & 9 & 2 \\
\hline Піррос Д. & Греція & 83,85 & 13 & 9 & 3 \\
\hline Разорьонов ї. & Україна & 105 & 12 & 11 & 3 \\
\hline Ван Шінюан & Тайвань & 52,56 & 12 & 8 & 2 \\
\hline Мутлу X. & Туреччина & 52,56 & 11 & 11 & 4 \\
\hline Готфрид Д. & Україна & 105 & 11 & 6 & 3 \\
\hline Чимеркін А. & Росія & +105 & 11 & 9 & 2 \\
\hline Мінчев С. & Болгарія & 56,62 & 10 & 10 & 3 \\
\hline Реза-Заде X. & Їран & +105 & 10 & 8 & 2 \\
\hline Хустер М. & Німеччина & 83,85 & 10 & 10 & 3 \\
\hline Йотов Й. & Болгарія & 67,$5 ; 77$ & 9 & 9 & 2 \\
\hline Чжан Сюань & Китай & 77 & 8 & 7 & 2 \\
\hline
\end{tabular}

Примітка. МР - максимальний результат

Таблиця 4 - Терміни досягнення максимальних результатів найсильнішими важкоатлетками світового рівня

\begin{tabular}{|c|c|c|c|c|c|}
\hline \multirow[b]{2}{*}{ Спортсменка } & \multirow[b]{2}{*}{ Країна } & \multirow[b]{2}{*}{$\begin{array}{c}\text { Вагова } \\
\text { категорія, кг }\end{array}$} & \multicolumn{3}{|c|}{ Терміни досягнення, роки } \\
\hline & & & $\begin{array}{l}\text { Тривалість періоду } \\
\text { успішних виступів }\end{array}$ & $\begin{array}{c}\text { Терміни } \\
\text { досягнення MP }\end{array}$ & $\begin{array}{c}\text { Кількість чотирирічних } \\
\text { макроциклів, де були } \\
\text { показані МР }\end{array}$ \\
\hline Трендафілова М. & Болгарія & 70,75 & 15 & 15 & 3 \\
\hline Кірілова Г. & Болгарія & 59,60 & 14 & 13 & 3 \\
\hline Крістофоріду М. & Греція & 64,69 & 14 & 14 & 3 \\
\hline Чу Нанмей & Тайвань & 48,50 & 13 & 13 & 3 \\
\hline Кім Донь Хі & Корея & 67,$5 ; 75$ & 13 & 13 & 3 \\
\hline Брайк Т. & Канада & 67,$5 ; 75$ & 13 & 13 & 3 \\
\hline Мінчева Д. & Болгарія & 46,48 & 11 & 11 & 2 \\
\hline Драгнєва İ. & Болгарія & 50,53 & 11 & 5 & 3 \\
\hline Шаймарданова В. & Україна & +75 & 11 & 11 & 2 \\
\hline Лундал К. & Фінляндія & 83 & 11 & 8 & 2 \\
\hline Чень Джулайн & Тайпей & 59,63 & 10 & 10 & 3 \\
\hline Джонсон О. & США & 67,$5 ; 75$ & 10 & 10 & 2 \\
\hline Чен Шичі & Тайвань & +75 & 10 & 9 & 2 \\
\hline Хоміч А. & Росія & 83 & 10 & 10 & 2 \\
\hline Мері Л. & Франція & +75 & 9 & 9 & 2 \\
\hline Хасеба К. & Японія & 67,5 & 9 & 5 & 2 \\
\hline Уррутія М.-ї. & Колумбія & 82,5 & 9 & 9 & 2 \\
\hline Врубель А. & Польща & +75 & 8 & 8 & 2 \\
\hline Скакун Н. & Україна & 58,63 & 7 & 5 & 2 \\
\hline
\end{tabular}


ся від 4 (Тань Вейфань, Китай) до 15 років (Мілена Трендафілова, Болгарія). Середньогрупові показники не мають суттєвого зростання з підвищенням груп вагових категорій спортсменок: у першій групі $-8,9 \pm 0,8$ року, другій $-9,3 \pm 0,6$ року та третій $-9,4 \pm 0,5$ року. Різниця між груповими показниками на відповідних етапах багаторічного вдосконалення між чоловіками та жінками першої групи становить - 2,1 року ( $<0,05)$, третьої відповідно 2,3 року ( $<<0,05)$. Таким чином, бачимо, що у жінок висока результативність на відповідних етапах багаторічної підготовки в середньому на два роки менша, ніж у чоловіків.

Тривалість періодів збереження високих досягнень найсильнішими спортсменками світу за свою спортивну кар'єру має такі тенденції: якщо тривалість перебування на етапах багаторічної підготовки прийняти за 100 \% для всіх жінок, то у першій групі вони були показані після проходження 94,0 \pm 2,4 \% всього періоду підготовки, у другій та третій групах $-93,8 \pm 3,2$ і 90,3 \pm 3,3 \% відповідно. Тобто відмічається тенденція, коли спортсменки демонструють найвищу результативність наприкінці етапу збереження досягнень. Серед досліджуваної групи більшість спортсменок (53,3%) показали найвищу результативність в останній рік перебування на п'ятому й шостому етапах багаторічного вдосконалення, а інші спортсменки - протягом другої половини відповідних етапів спортивного вдосконалення.

Таким чином, аналіз отриманих результатів свідчить, що переважна більшість спортсменівчоловіків (65,0 \%) має терміни досягнення високої результативності 6-10 років, 24,0 \% демонструють їі в межах 11 років і більше. Найбільш високу результативність мають кілька найвидатніших важкоатлетів сучасності: Леонід Тараненко (Білорусь) - 17 років, який ще у далекому 1979 р. виборов бронзову медаль на чемпіонаті світу, а завершив спортивну кар'єру на чемпіонаті Європи 1996 р. в Ставангорі (Норвегія); Микола Пєшалов (Болгарія/ Хорватія) - 16 років; триразовий олімпійський чемпіон Піррос Дімас (Греція) та Манфред Нерлінгер (Німеччина) - по 15 років відповідно.

У жінок подібні розрахунки мають дещо іншу тенденцію: переважна більшість спортсменок (72 \%) має терміни досягнення високої результативності на відповідних етапах багаторічного вдосконалення у середньому від 5 до 10 років і на неї не впливає їхня вагова категорія. Так, наприклад, Кім Сун Хі (Корея, вагова категорія + 75 кг) має терміни досягнення високої результативності на четвертому-шостому етапах багаторічної підготовки - у межах 14 років; Мілена Трендафілова (Болгарія, категорія 70 кг) - 16 років, Марія Такач (Угорщина, 70-75 кг) - 12 років; Чу Ненмей (Тайбей, 48 кг) - 13 років; Намейракпам Кунджарані (Індія, 44 кг) та Ізабелла Драгнева (Болгарія, 53 кг) - по 11 років. Отже, терміни досягнен-
Таблиця $\mathbf{5}$ - Вікові межі виконання спортивних нормативів найсильнішими важкоатлетами України різної статі та вагових категорій, роки

\begin{tabular}{|c|c|c|c|c|}
\hline \multirow{2}{*}{ Етапи підготовки } & \multirow{2}{*}{ Стать } & \multicolumn{3}{|c|}{ Групи вагових категорій } \\
\hline & & Перша & Друга & Третя \\
\hline \multirow[t]{2}{*}{ Початок підготовки, вік } & 4. & 12,7 & 11,6 & 13,2 \\
\hline & ж. & 13,6 & 13,3 & 13,5 \\
\hline \multirow{2}{*}{$\begin{array}{l}\text { Виконання нормати- } \\
\text { ву МС }\end{array}$} & 4. & 18,0 & 16,4 & 17,3 \\
\hline & ж. & 15,7 & 15,3 & 16,4 \\
\hline \multirow{2}{*}{$\begin{array}{l}\text { Виконання нормати- } \\
\text { ву МСМК }\end{array}$} & 4. & 23,8 & 20,0 & 20,4 \\
\hline & ж. & 20,1 & 17,2 & 18,1 \\
\hline \multirow{2}{*}{$\begin{array}{l}\text { Досягнення п'ятого } \\
\text { етапу багаторічного } \\
\text { вдосконалення }\end{array}$} & 4. & 21,9 & 20,8 & 21,0 \\
\hline & ж. & 19,2 & 20,0 & 20,1 \\
\hline
\end{tabular}

ня спортивної результативності важкоатлетів на етапах багаторічного вдосконалення, на нашу думку, залежать: по-перше, від структури змагальної діяльності того чи іншого спортсмена, а також від чинників, що визначають ефективність цієї структури; по-друге, від індивідуальних задатків і здібностей спортсменів.

Дискусія. Твердження про те, що важкоатлети різної статі та груп вагових категорій мають значні відмінності у вікових межах на початку занять видом спорту, а також під час виконання спортивно-класифікаційних нормативів (нормативу майстра спорту та майстра спорту міжнародного класу) підтвердив у своїх дослідженнях О. І. Пуцов (табл. 5) [15].

Аналізу підлягали результати тільки перспективних важкоатлетів, які у подальшому увійшли до основного складу збірної команди України. Вік важкоатлетів-чоловіків на початку підготовки становив 12-13 років, у жінок - 13-14 років. Норматив майстра спорту спортсмени різної статі виконують також неодночасно: чоловіки через 4-5 років занять - у 16-18 років, жінки у два рази швидше, через 2-3 роки, тобто у 15-17 років. Ця тенденція підтверджується швидшим статевим дозріванням дівчат, які спеціалізуються у важкій атлетиці. Отже жінки проходять три перших етапи (початкової, попередньої базової та спеціалізованої базової підготовки) приблизно удвічі швидше, ніж чоловіки.

Норматив майстра спорту міжнародного класу обстежувана група спортсменів також виконує у різні терміни: чоловіки через 3-6 років після виконання нормативу майстра спорту, тобто у 19-24 роки, жінки удвічі швидше, через 1,5-2,5 року після виконання нормативу майстра спорту, тобто у 17-20 років.

Ще одна тенденція, яка більше простежується у чоловіків, ніж у жінок, це зменшення термінів виконання нормативу майстра спорту та майстра спорту міжнародного класу 3 підвищенням 
Таблиця 6 - Приблизна тривалість етапів багаторічної спортивної діяльності (за Л. П. Матвєєвим [6]).

\begin{tabular}{|c|c|c|}
\hline \multirow{2}{*}{ Етап } & Стадія & \multirow{2}{*}{ Тривалість, роки } \\
\hline & Базової підготовки & \\
\hline 1 & $\begin{array}{l}\text { Початковий базово-підготовчий (етап залучення до занять спортом, початкової спортивної } \\
\text { орієнтації та загальної базової підготовки) }\end{array}$ & $1-3$ \\
\hline \multirow[t]{2}{*}{ II } & $\begin{array}{l}\text { Основний базово-підготовчий (етап уточнення і початку поглибленої спортивної спеціаліза- } \\
\text { ції та етапу спеціалізованої базової підготовки) }\end{array}$ & \multirow[t]{2}{*}{$2-3$} \\
\hline & Максимальної реалізації індивідуальних можливостей & \\
\hline III & $\begin{array}{l}\text { Передкульмінаційний (етап розгортання поглибленої спортивної спеціалізації з найповні- } \\
\text { шою активізацією спортивної діяльності; для обдарованих спортсменів - це етап переходу } \\
\text { до спортивного професіоналізму) }\end{array}$ & $2-4$ \\
\hline \multirow[t]{2}{*}{ IV } & $\begin{array}{l}\text { Кульмінаційний (етап найактивнішої спортивної діяльності, поєднаний з індивідуально- } \\
\text { максимальними досягненнями) }\end{array}$ & \multirow[t]{2}{*}{$4-5$} \\
\hline & Завершальна (етап спортивного довголіття) & \\
\hline V & Стабілізаційний (етап підтримання досягнутого рівня спортивної результативності) & $4-6$ \\
\hline VI & $\begin{array}{l}\text { Перехідно-загально-кондиційний (етап переходу на фізкультурно-спортивну діяльність, } \\
\text { схожий на загально-кондиційне тренування) }\end{array}$ & $\begin{array}{l}\text { Без визначених } \\
\text { часових меж }\end{array}$ \\
\hline
\end{tabular}

груп вагових категорій. Пояснення цій тенденції, на нашу думку, може бути таким: спортсмени, які змінюють вагову категорію на вищу, прогресують швидшими темпами за рахунок набраної активної м'язової маси, що дозволяє їм показувати вищий результат у змагальних вправах та сумі двоборства.

Відомо, що чим триваліший етап підготовки спортсмена, тим менша вірогідність збігу запланованих досягнень 3 реальними. Як орієнтири для часових термінів досягнення етапів спортивного вдосконалення та виконання класифікаційних нормативів спортсменами можна використовувати дані Л. М. Матвєєва [6, 7] про тривалість великих етапів багаторічної підготовки, які у сукупності становлять три послідовні стадії (табл. 6).

Такі або близькі до них терміни етапів багаторічної спортивної діяльності подаються у науковометодичних публікаціях 3 важкої атлетики. Так, наприклад, О. С. Медведєв [8] вважає, що етап відбору та початкової підготовки важкоатлетів повинен тривати у середньому до двох років, етап становлення спортивної майстерності - близько трьох років, а етап досягнення вищої спортивної майстерності - близько чотирьох років. Підготовка у складі збірної команди може тривати доти, поки спортсмен демонструє досягнення міжнародного рівня (входить за рейтингом до десятки найсильніших важкоатлетів у відповідній ваговій категорії).

На думку Л. С. Дворкіна [4], увесь процес становлення спортивної майстерності важкоатлетів реалізується шляхом подолання ступенів та нормативів Сдиної спортивної класифікації. Автор зробив першу спробу створити формалізовану модель процесу багаторічної підготовки для юних важкоатлетів у віковому діапазоні від 12 до 22 років. До такої формалізованої моделі він вклю- чив такі етапи: попередньої і початкової підготовки; навчально-тренувальний етап; етап спортивного вдосконалення та етап вищої спортивної майстерності. Трохи згодом він запропонував розділити багаторічну підготовку важкоатлетів на п'ять етапів:

- попередньої підготовки (з 13 років із середньою тривалістю 3 роки);

- початкової спортивної спеціалізації (тривалість 2 роки);

- поглибленого тренування (тривалість 3 роки);

- удосконалення спортивної майстерності (тривалість 2 роки);

- вищої спортивної майстерності (від 21 року).

Таким чином, згадані автори дотримуються однакової думки про те, що тривалість визначених етапів багаторічного вдосконалення зумовлена не стільки календарним (паспортним) віком спортсменів, скільки їхнім біологічним віком, що розраховується за ознаками біологічного дозрівання та інволюції морфофункціональних властивостей організму, а також за реально побудованим змістом системи підготовчої та змагальної діяльності спортсмена.

Під час комплектування основних складів збірних команд країни автори рекомендують порівнювати досягнення та потенційні можливості спортсменів різного віку. У цьому випадку молодший спортсмен має перевагу над старшим за віком спортсменом. Потім аналізуються досягнення спортсменів різного віку, за якими здійснюється спортивна селекція:

- визначаються оптимальні вікові межі для показу найвищих досягнень в обраному виді спорту;

- здійснюється прогноз рівня спортивних досягнень призерів чемпіонатів світу до найближчих Ігор Олімпіад; 
- визначається вікова динаміка спортивних досягнень найсильніших спортсменів у конкретному виді спорту.

Дещо іншої думки про вікові межі та тривалість етапів багаторічної підготовки важкоатлеток дотримується російський фахівець П. С. Гурильов [2], який обгрунтував необхідність виділення чотирьох етапів багаторічної підготовки.

Перший етап автор назвав етап відбору та початкової підготовки спортсменок із віковими показниками дівчат 7-8 років. На цьому етапі він пропонує відбирати обдарованих та здібних до важкої атлетики дівчат з метою зміцнення їхнього здоров'я, сприяння фізичному розвитку, різнобічної рухової підготовки для розвитку фізичних якостей, навчання основ техніки, виховання мотивації до занять важкою атлетикою. На думку автора, такий ранній етап відбору та початкової підготовки дівчат у видах спорту швидкісно-силової та силової спрямованості пов'язаний із специфікою гормональної активності організму.

На другому етапі - початкової спеціалізації із віковими показниками дівчат 9-11 років здійснюється всебічна фізична підготовка, розвиток фізичних якостей, формування техніки, виховання вольових якостей, розвиток функціональної підготовленості, формування стійкої рухової навички у важкоатлетичних вправах.

На третьому етапі - поглибленої спеціалізації - із віковими показниками дівчат 12-14 років усі процесі пов'язані із досягненням ними пубертатного періоду розвитку і відповідно зі зміною гормонального фону організму. Цей етап характеризується появою ОМЦ з метою збереження репродуктивних функцій організму спортсменок, i тому потребує індивідуального підходу до планування їхніх тренувальних навантажень.

На четвертому етапі, який охоплює дві самостійні вікові межі спортсменок (спортивного вдосконалення із віковими показниками 15-16 років та вищої спортивної майстерності із віковими показниками відповідно 17-18 років і старші) здійснюється подальша підготовка зі збереженням здоров'я та функціонального стану за рахунок досягнення високого рівня загальної та спеціальної фізичної підготовленості, подальшого вдосконалення технічної та тактичної підготовленості, сталості спортивних результатів, оволодіння знаннями, вміннями та навичками управляти своєю спортивною формою, у тому числі під час підготовки до головних змагань року.

Таким чином, пропозиції цього вченого щодо встановлення вікових меж та тривалості етапів багаторічної підготовки важкоатлеток небагато суперечать з отриманими нами даними про вік початку занять важкою атлетикою. Якщо взяти середній вік початку занять спортсменок Китаю, який становить 10-12 років, то за даними П. С. Гурильова [2], ці атлетки повинні бути на другому, а деякі і на третьому етапі багаторічної підготовки, що викликає деякі сумніви.

Моделювання вікових меж на етапах становлення вищої спортивної майстерності важкоатлетів завжди було у полі зору фахівців, які працюють у спорті вищих досягнень. За результатами отриманих даних, фахівцями встановлено, що незалежно від етапів спортивної підготовки орієнтиром для високих спортивних результатів є чинники становлення вищої спортивної майстерності, котрі характерні для найсильніших спортсменів обраної спеціалізації. Водночас не завжди досліджувались загальні терміни тривалості підготовки важкоатлетів, що передували етапам реалізації індивідуальних можливостей та збереження досягнень.

На думку учених [1, 4, 10], подальше вивчення вікових меж найвищих досягнень важкоатлетів є однією із головних характеристик удосконалення організаційно-методичних систем багаторічної підготовки. Досягнення вершинспортивної майстерності можливе лише за умови побудови багаторічного тренування спортсмена із урахуванням закономірностей термінів становлення спортивної майстерності в конкретній спеціалізації. У загальному вигляді ці закономірності виявляються через оптимальні вікові межі багаторічної підготовки і їі окремі етапи, а також вікову динаміку темпів становлення спортивної майстерності.

Принципова складова в процесі становлення вищої спортивної майстерності - вік продовження підготовки на етапі максимальної реалізації індивідуальних можливостей. Можна навести багато прикладів того, що найбільших успіхів досягають спортсмени, чия підготовка підлягала значній спеціалізації й інтенсифікації у сприятливому для цього віці. Фахівці із єдиноборств початок етапу максимальної реалізації індивідуальних можливостей зазвичай пов'язують із виконанням нормативу майстра спорту. За даними деяких учених [10], у важкоатлетів цей вік, зазвичай, становить 16-18 років.

Таким чином, аналіз вікових меж найсильніших важкоатлетів світу, що впливають на терміни становлення їхньої спортивної майстерності, дає змогу зробити такі висновки: жінки проходять перші етапи багаторічного вдосконалення швидше за чоловіків (у середньому на два роки), але вони витрачають більше часу на виконання спортивнокласифікаційного нормативу майстра спорту міжнародного класу та досягнення етапу максимальної реалізації індивідуальних можливостей. Такий висновок зумовлює нас рекомендувати для тренерів індивідуально-групові й узагальнені вікові межі термінів становлення спортивної майстерності для спортсменів різної статі та груп вагових категорій.

\section{Висновки:}

1. Терміни проходження важкоатлетками першої стадії процесу багаторічного вдосконалення 
суттєво менші (на 1,0-3,5 року), ніж у чоловіків. Жінки витрачають, зазвичай, менший часовий термін на період входження до групи світових лідерів (на 1-2 роки), порівняно з чоловіками. Але чоловіки довший час зберігають високу результативність на другій стадії процесу багаторічного вдосконалення - 11-14 років, тоді як у жінок він становить тільки 8-11 років.

2. Аналіз вікових меж спортивних досягнень важкоатлетів-чоловіків високої кваліфікації за спортивну кар'єру, але у різні часові періоди підготовки свідчить, що тривалість їх підготовки у перший часовий період становила у середньому 9,1 року із віком досягнення цього етапу - 20,9 року, тоді як тривалість підготовки у другий часовий період зросла на 15,0 \% і становила - 10,7 року із віком досягнення цього етапу - 18,3 року.

Якщо у перший часовий період тренувального процесу вік спортсменів на початку занять важкою атлетикою становив у середньому 15,9 року, то у другий часовий період він суттєво зменшився - на 22,6 \% та становив уже 12,3 року. Середній вік завершення п'ятого етапу багаторічної підготовки важкоатлетів світового рівня протягом двох вікових періодів майже не має відмінностей і становить 30,3 та 29,6 року відповідно.

3. Вікові межі входження важкоатлетів-чоловіків і жінок Китаю до групи світових лідерів (друга стадія підготовки) після участі у національних чемпіонатах становлять: для чоловіків - 22 роки (у середньому через 1-2 роки), у жінок - 18-20 років відповідно (у середньому через 0,5-1 рік). Мають також відмінності вікові межі, в яких важкоатлети елітної групи різної статі зберігають свої високі спортивні результати та завершують свою кар'єру: у чоловіків вони ста- новлять - 28-31 років, у жінок - на 2-3 роки менше, у 26-28 років відповідно.

4. Вивчення термінів збереження максимальних результатів найсильнішими важкоатлетами світу на етапах багаторічного вдосконалення різних груп вагових категорій показало різні терміни їх досягнення за всю спортивну кар'єру: у першій групі після 90,9 \pm 3,3 \% терміну, у другій групі - відповідно 84,2 \pm 3,6 \% у третій групі $-74,5 \pm 3,2 \%(p<0,05)$. У жінок дещо інша тенденція: у першій групі вони були показані після $-94,0 \pm 2,4 \%$ всього терміну, у другій та третій групах $-93,8 \pm 3,2$ і 90,3 \pm 3,3 \% відповідно Тобто відмічається тенденція, коли спортсменки демонструють найвищу результативність наприкінці етапу збереження досягнень.

5. Середньогрупові темпи зростання досягнень у жінок не мають суттєвих відмінностей із підвищенням груп вагових категорій: у першій групі $8,9 \pm 0,8$ року, другій $-9,3 \pm 0,6$ року, у третій $9,4 \pm 0,5$ року. У них висока результативність на етапах багаторічного вдосконалення в середньому на два роки менша, ніж у чоловіків. У чоловіків 65,0 \% важкоатлетів мають терміни досягнення високої результативності - 6-10 років, а 24,0 \% із них показують її в межах 11 років і більше. У жінок $72 \%$ спортсменок мають відповідні терміни у середньому від 5 до 10 років і на них не впливає їхня вагова категорія.

Перспективи подальших досліджень можуть бути пов'язані з визначенням темпів досягнень та вікових меж найсильніших важкоатлетів світу, показаних на Іграх XXXII Олімпіади в Токіо.

Конфлікт інтересів. Автори заявляють, що відсутній будь-який конфлікт інтересів.

\section{Література}

1. Бубка СН, Платонов ВН. Менеджмент подготовки спортсменов к Олимпийским играм; 2017. 480 с.

2. Горулев ПС. Управление спортивной подготовкой женщин в тяжелой атлетике с учетом демографических различий работоспособности: [автореферат]. Челябинск: 2006. 45 с.

3. Горулев ПС, Румянцева ЭР. Женская тяжелая атлетика: проблемы и перспективы: Учеб. пособие для студ. Москва: Сов. спорт; 2006: 164 с.

4. Дворкин ЛС. Тяжелая атлетика: учебник для вузов. Москва: Сов. спорт; 2005. 597 с.

5. Денискин ВН, Медведев АС. Уровень спортивных достижений в зависимости от весовой категории у сильнейших тяжелоатлетов КНР. Юбил. сбор. труд. учен. РГАФК. Москва: 1998. 5: 16-9.

6. Матвеев ЛП. Основы общей теории спорта и системы подготовки спортсменов. Киев: Олимпийская лит.; 1999. 320 с.

7. Матвеев ЛП. Общая теория спорта и ее прикладные аспекты: учеб. для вузов фриз. культуры. Москва: Сов. спорт; 2010. 340 с.

8. Медведев АС. Многолетняя динамика спортивного мастерства в рывке и толчке у сильнейших тяжелоатлеток мира. Теория и практика фризической культуры. 1997; 3: 9-12.

9. Олешко ВГ. Підготовка спортсменів у силових видах спорту: навч. посіб. Київ: ДІА; 2011. 444 с.

10. Олешко ВГ. Моделювання, відбір та орієнтація в системі підготовки спортсменів (на матеріалі силових видів спорту) [автореферат]. Київ. 2014. 38 с.

11. Олешко ВГ. Теорія та методика тренерської діяльності у важкій атлетиці. Київ: Олімп. л-ра; 2018. 332 с.

12. Олешко В, Деха Н, Янг ТанСунг, Мухін Є. Динаміка спортивних досягнень важкоатлетів світового рівня після введення нових вагових категорій. Теорія та методика фріз. виховання і спорту. 2019; (1): 36-41.

13. Платонов ВН. Периодизация спортивной тренировки. Общая теория и ее практическое применение. Киев: Олимпийская лит.; 2013. 624 с. 
14. Платонов ВН. Система подготовки спортсменов в олимпийском спорте. Общая теория и ее практические приложения. Киев: Олимпийская лит.; 2015. 1: 680 с. 2: 752 с.

15. Пуцов СО. Побудова тренувального процесу важкоатлеток високої кваліфікації у річному макроциклі [авторефрерат]. Київ. 2008: 20 c.

16. Drechsler A. The weightlifting encyclopedia: a guide to world class performance. Published by: a is a communications, flushing. N.Y., 1998: 549 p.

17. Malcata R., Hopkins W. Variability of competitive performance of elite athletes: a systematic review. Sports Med. 2014; 44:1763-1774.

18. Solberg P, Hopkins W, Paulsen G. Haugen T. Peak age and performance progression in world-class weightlifting and powerlifting athletes. International Journal of Sports Physiology and Performance. Oslo, Norway. March 2019.

19. Storey A, Smith $\mathrm{H}$. Unique aspects of competitive weightlifting: performance, training and physiology. Sports Med. 2012; 42:769-790.

\section{Literature}

1. Bubka SN, Platonov VN. Management of athlete preparation for the Olympic games; $2017.480 \mathrm{p}$.

2. Gorulev PS. Managing sports preparation of women in weightlifting with account for demographic differences in work capacity: [author's abstract]. Chelyabinsk: 2006. 45 p.

3. Gorulev PS, Rumyantseva ER. Women's weightlifting: issues and prospects: Teaching guide. Moscow: Sov. sport; 2006: 164 p.

4. Dvorkin LS. Weightlifting: textbook for institutions. Moscow: Sov. sport; 2005. 597 p.

5. Deniskin VN, Medvedev AS. Level of sports achievements in best Chinese weightlifters depending on weight category. Yubil. sbornik trud. uchen. RGAFK. Moscow: 1998. 5: 16-9.

6. Matveyev LP. Bases of general sports theory and system of athletes' preparation. Kiev: Olimpiyskaya literatura; 1999. 320 p.

7. Matveyev LP. General sports theory and its practical applications: textbook for physical culture institutions. Moscow: Sov. sport; 2010. 340 p.

8. Medvedev AS. Long-term dynamics of sports mastery in jerk and push in world best weightlifters. Teoriya praktika fizicheskoy kultury. 1997; 3: 9-12

9. Oleshko VG. Athletes' preparation in strength sports events: teaching guide. Kyiv: DIA; 2011. 444 p.

10. Oleshko VG. Modeling, selection and orientation in the system of athletes' preparation (strength sports events) [author's abstract]. Kyiv. 2014. 38 p.

11. Oleshko VG. Theory and methods of coach activity in weight lifting. Kyiv: Olimpiyska literatura; 2018. 332 p.

12. Oleshko V, Dekha N, Young TanSung, Mukhin I. Dynamics of sports achievements of wprld level weightlifters after introducing new weight categories. Teoriia i metodyka fizvykhovannia i sportu. 2019; (1): 36-41.

13. Platonov VN. Sports training periodization. General theory and its practical applications. Kiev: Olimpiyskaya literatura; 2013. $624 \mathrm{p}$

14. Platonov VN. System of athletes' preparation in the Olympic sport. General theory and its practical applications. Kiev: Olimpiyskaya literatura; 2015. 1: 680 p. 2: 752 p.

15. Putsov SO. Training process design for highly skilled weightlifters in annual macrocycle [author's abstract]. Kyiv. 2008: $20 \mathrm{p}$

16. Drechsler A. The weightlifting encyclopedia: a guide to world class performance. Published by: a is a communications, flushing. N.Y., 1998: 549 p.

17. Malcata R., Hopkins W. Variability of competitive performance of elite athletes: a systematic review. Sports Med. 2014; 44:1763-1774.

18. Solberg P, Hopkins W, Paulsen G. Haugen T. Peak age and performance progression in world-class weightlifting and powerlifting athletes. International Journal of Sports Physiology and Performance. Oslo, Norway. March 2019

19. Storey A, Smith H. Unique aspects of competitive weightlifting: performance, training and physiology. Sports Med. 2012; 42:769-790.

\section{Інформація про авторів}

Олешко Валентин Григорович, orcid.org/0000-0003-4798-90901. valentin49@ukr.net;

Національний університет фрізичного виховання і спорту України, вул. Фізкультури 1, м. Київ, 03150, Україна

\section{Information about the authors}

Oleshko Valentyn

orcid.org/0000-0003-4798-90901. valentin49@ukr.net;

Національний університет фрізичного виховання і спорту України, вул. Фізкультури 1, м. Київ, 03150, Україна 